\title{
Lolium multiflorum SEEDS IN THE SOIL: I. SOIL SEED BANK DYNAMICS IN A NO TIL SYSTEM $^{1}$
}

\author{
FERNANDA COSTA MAIA², MANOEL DE SOUZA MAIA ${ }^{3}$, RENÉE M. BEKKER ${ }^{4}$, ROGÉRIO PREVIATTI BERTON ${ }^{5}$, LEANDRO \\ SEBASTIÃO CAETANO ${ }^{5}$
}

\begin{abstract}
RESUMO - O estudo objetivou a caracterização da dinâmica de populações de sementes de azevem anual em manejo de revegetação, em um sistema de plantio direto em rotação com soja, em diferentes seqüências. A soja foi cultivada por dois anos e cultivada novamente depois de dois anos de pousio. As quatro seqüências representaram diferentes períodos de manejo, dois deles com soja (6 e 8 anos) e os outros dois restantes ( 3 e 9 anos). Amostras de solos foram tomadas a cada mês, durante um ano, em duas profundidades (0-5 e 5-10 cm). A dinâmica de vegetação foi também avaliada (numero de plantas, inflorescências e plântulas). A dinâmica do banco de sementes do solo (SSB) mostrou padrão estrutural no tempo, com um período de armazenamento no verão, um período de exaustão durante o outono e um período de transição no inverno e primavera. O estabelecimento de pastagem por revegetação natural 'e' totalmente dependente do banco de sementes do solo. A influ^encia das praticas de manejo no SSB e mais importante do que o numero de anos que estas praticas tem sido implementadas. Locais onde a soja foi cultivada mostraram maior SSB. A maior parte das sementes teve sua dormência quebrada e germinaram no final do período de verão e começo do outono, mostrando um típico SSB transitório, mas com pequena proporção de sementes persistentes.
\end{abstract}

Palavras chaves: azevem annual, pastagem annual, soja, pastagens, plantio direto.

\section{Lolium multiflorum SEEDS IN THE SOIL: I. SOIL SEED BANK DYNAMICS IN A NO TIL SYSTEM $^{1}$}

\begin{abstract}
The objective of the study was to characterize annual ryegrass seed population dynamics, managed for natural re-sowing, in no til systems in rotation with soybean, in different chronosequences An area was cultivated for two years with soybean, left as fallow land for the next two years and then cultivated again with soybean for the next two years. The four chronosequences represented different management periods, two with soybean (6 and 8 years old) and the other two resting ( 3 and 9 years old). Soil samples were taken every month during one year and divided into two depths (0-5 and 5-10 cm). Vegetation dynamics were also evaluated (number of plants, inflorescences and seedlings). Soil seed bank (SSB) dynamics showed structural patterns in time, with a "storage period" in summer, an "exhausting period" during autumn and a "transition period" in winter and spring. Pasture establishment by natural re-sowing was totally dependent on the annual recruitment of seeds from the soil. The influence of the management practices on the SSB was more important than the number of years that these practices had been implemented. Places where soybean was sown showed the largest SSBs. Most of the seeds overcame dormancy and germinated at the end of the summer and beginning of the autumn, showing a typically transitory SSB, but with a small proportion of persistent seeds.
\end{abstract}

Index terms: annual ryegrass, buried seeds, soybean, grasslands, no til system.

${ }^{1}$ Submitted in 02/08/2007. Accepted in 08/03/2008. Part of the Thesis of
the first author, presented to Post-Graduation Program of Seed Science and
Technology, Federal University of Pelotas, Pelotas-RS, Brazil. Financial support
by CNPq. ${ }^{2}$ Agr. Eng., Researcher, Dr. State Foundation of Agricultural Research
BR 392, km 36, Domingos Petrolini, Rio Grande-RS, Brazil (E-mail:fecmaia@ terra.com.br). ${ }^{3}$ Professor, Dr. Federal University of Pelotas, Department of Plant Science, P.O.Box 354, Pelotas-RS, Brazil. ${ }^{4}$ Biol., Researcher, Dr. University of Groningen, Community and Conservation Ecology Group, Groningen, The Netherlan ${ }^{\text {ds. }}{ }^{5}$ Students, Agronomy Course, Federal University of Pelotas, Pelotas-RS, Brazil. 


\section{INTRODUCTION}

In the South of Brazil, the distribution of the grassland productivity throughout the year is typically seasonal due to the occurrence of low temperatures during the winter, which impairs vegetation growth of the predominantly subtropical species (spring/summer life cycle) (Barcellos et al., 2002; Maia et al., 2003). In the state of Rio Grande do Sul, such situation causes the death of approximately $5 \%$ of the total herd (Maia and Primo, 1995). Rio Grande do Sul plays an important role in the exportation of Brazilian beef, as Brazil has become the largest beef-exporting country of the world since 2003 (IBGE, 2005). One of the practices used to avoid the seasonal problem of grassland productivity, is the introduction of exotic winter species by the management of natural re-sowing as an attempt to reduce the costs of forage production.

Due to its dormancy and its nutritional value for cattle, annual ryegrass (Lolium multiflorum Lam.) is one of the most used grasses in the Southern part of Brazil in crop rotation systems with soybean, dispersing its seeds before soybean sowing, which allows the natural re-sowing of the grass. However, it is still not clear for how long these fields can maintain high indexes of productivity and what the seed dynamics in the soil is like, in areas that are exclusively based on natural re-sowing.

In regard to the succession between annual ryegrass and soybean in no tillage systems, good results have been obtained, although there is a lack of studies that aim at qualifying the decisions related to the "opportunity costs" to use annual ryegrass for grazing and management for natural re-sowing (Medeiros, 2000). Ayala (2002) found it important to understand the patterns of emergence and seed viability in the soil, as a way to strongly improve the seed bank activation index of some interesting species.

The soil seed bank may play an important role in the productive system, making feasible the use of the pasture (Silva, 2004). The economic success of a forage species introduction in natural grasslands depends on how long this species keeps on producing. In general, the persistence is highly correlated to the adoption of adequate management practices and natural re-sowing capacity from the soil seed bank (Marañon, 1995; Medeiros, 2000).

According to some authors, several cultivated grasses, including Lolium spp., do not have persistent soil seed banks (Douglas, 1965; Thompson and Grime, 1979; Howe and Chancellor, 1983; López-Mariño, 2000), indicating that re- sowing, observed in improved grasslands, is basically from seeds deposited in the soil in the previous season.

Most researchers describe the composition, diversity and density of the seed bank but do little to explain how those qualities arise and how quickly they change (Fenner and Thompson, 2005). Researches about population dynamics of these improved grasslands and its relationship with soil seed banks in medium and long period should be proposed. For this, studies that aim at determining the soil seed bank in all seasons of the year and the population dynamics of the species will allow a better comprehension of the dynamics of the grasslands under agricultural use, to offer information to make possible the adoption of management practices in crop systems viewing the optimization of the economical use of these grasslands and assure their sustainability.

This study aimed at characterizing L. multiflorum seed population dynamics in no tillage systems in rotation with soybean, in different chronosequences.

\section{MATERIAL AND METHODS}

\section{Study area}

The study was carried out in the South of Brazil, in Pelotas, in the Southeast of Rio Grande do Sul state, Brazil, $31^{\circ} 38^{\prime} 00^{\prime \prime S}$ and $52^{\circ} 27^{\prime} 00^{\prime \prime} \mathrm{W}$, from December/2002 to December/2003.

The climate is considered to be subtropical in general, with four well defined seasons, well distributed rains throughout the year (1,300 to $1,500 \mathrm{~mm})$, annual medium temperature of $17^{\circ} \mathrm{C}$ and possible frosts from April to September. The area presents a wavy soft relief and loamy texture soils, not well drained, with good chemical and physical characteristics, deep and with excessive superficially compacted soil. The soil shows strong variation in the phosphorus and potassium indexes according to the depth. The $\mathrm{pH}$ varies from 4.4 to 5.1.

The area of the sites of study were around 100 ha, each one representing one chronosequence of utilization time of this crop system (3, 6, 8 and 9 years old). Four consecutive plots of 25 x 20 m were designed in each chronosequence. The study areas were chosen for having an intermediate relief position and being representative of the crop system used in the farm.

\section{No tillage system: annual ryegrass and soybean}

In the beginning, annual ryegrass was first sown (30 
$\mathrm{kg} \cdot \mathrm{ha}^{-1}$ ) in the artificially dried natural grassland. No sowing was carried out in the following years. The sites are divided with electric fences and used in rotative grazing by cattle in a medium capacity of 1.5 animal.ha ${ }^{-1}$.year ${ }^{-1}$, reaching a commercial flock productivity index of approximately 450 kg.ha-1.year-1 of living weight. The cattle grazing period usually takes place from June (end of autumn) to October (spring), when the animals are sold or managed to another area. That is when nitrogen is applied $\left(50 \mathrm{~kg} \cdot \mathrm{ha}^{-1}\right)$ to stimulate plant growth, seed production and an adequate formation of the SSB capable of guaranteeing the natural re-sowing. By the beginning of December (end of spring), glyphosate herbicide is used (1.25 to $2.0 \mathrm{~kg}^{-h a^{-1}}$ of the commercial product), allowing soybean to be sown 10 to 15 days after that. Soybean is harvested in April, when annual ryegrass plants are already in the area, reaching $15 \mathrm{~cm}$. Soybean is traditionally cultivated for two consecutive years and then the area is left uncultivated for the two next years. During the two years the area is not cultivated, the modified natural grassland is grazed and cut in the summer and annual ryegrass is grazed in the winter and managed for natural re-sowing.

Before glyphosate application, some seeds were collected to verify their maturity stage as indicated by their water content. During the study period, soybean was sown in two areas ( 6 and 8 years of utilization in no tillage system) whereas in the other two ( 3 and 9 years), soybean was not sown at all.

Soil variables were analysed in each area.

\section{Soil seed bank dynamics}

Ten soil samples (length of $10 \mathrm{~cm}$ and diameter of 5 $\mathrm{cm})$ were taken per plot, approximately every month during one year (from December 2002 to December 2003). A total of $1,963 \mathrm{~cm}^{3}$ were sampled in each plot, which agrees with some Japanese studies that recommend a minimum volume of soil ranging from 400 to $600 \mathrm{~cm}^{3}$ so that the seed bank can be correctly estimated in fields or grasslands (Numata et al., 1964; Hayashi and Numata, 1971).

Each sample was divided in two depths $(0-5 \mathrm{~cm}$ and $5-10 \mathrm{~cm}$ ). The samples were passed through sieves of 9.52 $\mathrm{mm}$ (to remove the above ground flora and stones), $1.68 \mathrm{~mm}$ and $0.84 \mathrm{~mm}$. The concentrated residue containing the seeds was examined and the annual ryegrass seeds were counted and removed. The seeds were placed in aluminium trays with sterilised soil of the area, in a room with controlled temperature, and periodically irrigated to verify their viability. Seeds that did not germinate were submitted to the tetrazolium test (Brasil, 1992).
The 3 year-old chronosequence was sampled just from December to May, when the area was not considered anymore in the experiment due to the fact that a new seeding of annual ryegrass and the correction of the soil surface with tractors was done by the farmer, as the area where the plot was located had flooding problems and few seeds survived.

Soil fertility in each chronosequence was analyzed in laboratory.

\section{Plant population dynamics}

In the middle of each plot, three contiguous quadrats of $0.5 \times 0.5 \mathrm{~m}\left(0.25 \mathrm{~m}^{2}\right)$ were used for a monthly population counting of annual ryegrass plants, for one year, determining the number of plants and the number of flower sets. According to the number of flower sets. $\mathrm{m}^{-2}$ in each chronosequence and the seed weight, in the end of November and beginning of December (end of spring), the potential seed number to increase the soil seed bank was calculated by an estimation of the number of seeds produced. $\mathrm{m}^{-2}$.

The number of seedlings was determined in three soil cores of $10 \mathrm{~cm}$ of diameter per plot.

\section{Statistic Analysis}

One-way ANOVA was done to soil seed bank data aiming at identifying not only the differences between the sites in each sampling time, but also between times in each site (chronosequence), using the software SPSS. The Levene Statistic for homogeneity of variances was performed before ANOVA. Regression analysis was also made with the same data to allow a better view of the soil seed bank dynamics throughout the year.

Multivariate analysis was performed with SSB and soil fertility data. Randomization test of soil fertility data was carried out using the software MULTIV (Pillar, 1997). The resemblance measurement used was the Gower index, as the variables have different units. With this test we tried to identify significant differences in soil fertility of the four chronosequences. Levene Statistic and One-way ANOVA were done to show which variables were responsible for these differences. With the software SYNCSA (Pillar and Orlóci, 1993), an ordination analysis was done. At the ordination diagram, the soil variables with the highest correlation indexes with at least one axe were also plotted. The diagram shows the position of each sample unit in the space, considering the amount of annual ryegrass seeds in the soil throughout the year, and the soil variables that can influence these positions. 


\section{RESULTS AND DISCUSSION}

The area with 3 years of management showed less viable seeds in the soil $\left(3,363\right.$ seeds. $\left.\mathrm{m}^{-2}\right)$, followed by the 9 yearold one $\left(6,623\right.$ seeds. $\left.\mathrm{m}^{-2}\right)$, both with no crop. The 6 and 8 year-old areas presented the largest soil seed banks, with 22,835 seeds. $\mathrm{m}^{-2}$ and 18,824 seeds. $\mathrm{m}^{-2}$, respectively. Periods with the highest seed numbers in the soil were the beginning of December (end of spring) for the 6 and 9 year-old areas and in the end of January (summer) for the 3 and 8 year-old areas. These differences in period are probably due to cattle management accomplished by the farmer, as the animals are not sold or transferred to another area at the same moment. If we incorporate to these results the number of non viable seeds, the size of the seed bank is to be found between 12,341 and 28,873 seeds. $\mathrm{m}^{-2}$.

With the observation of plant population dynamics of $L$. multiflorum, it was possible to know more about the annual potential of seeds that could constitute or not the soil seed bank of the area and about possible fluctuation of this flow of annually produced seeds. It is well known that one of the main factors responsible for seed production is the number of inflorescences per area (Silva, 2004). Considering the period with high number of seeds in the soil, the 3 year-old chronosequence showed a soil seed bank $56 \%$ lower, the area with 6 years a soil seed bank 9\% higher, with 8 years $4 \%$ higher and with 9 years a soil seed bank $44 \%$ lower. More than $90 \%$ of the seeds were in the first $5 \mathrm{~cm}$ from the soil surface.

Considering the periods with the largest soil seed banks, the areas with no crop were significantly different from the two areas where soybean was sown in the summer $(\mathrm{P}<0.05)$.

The soil fertility variables in each chronosequence were significantly different $(\mathrm{P}<0.05)$. The contrasts between the areas with and without soybean showed significant differences too $(\mathrm{P}<0.05)$. According to the Levene Statistic and One-way ANOVA, the soil of all areas have significant differences in their contents of clay, phosphorus, potassium, aluminium and calcium $(\mathrm{P}<0.05)$, as we can observe in Table 1 . The organic matter content was not different among the sites $(\mathrm{P}>0.05)$ and the other variables ( $\mathrm{pH}$, sodium and magnesium) could not be considered, as their variances were not homogeneous, according to the Levene Statistic $(\mathrm{P}<0.05)$.

TABLE 1. Changes in the contents of clay, organic matter, phosphorus, potassium, aluminum, and calcium at each chronosequence $(\mathrm{N}=4)$. Different symbols indicate significant differences between means using One-Way ANOVA followed by Tukey's range test $(\mathrm{P}<.05)$. Read horizontally only.

\begin{tabular}{ccccc}
\hline & 3 years-old & 6 years-old & 8 years-old & 9 years-old \\
\hline Clay & $13^{\mathrm{a}}$ & $14^{\mathrm{c}}$ & $15.75^{\mathrm{bc}}$ & $11^{\mathrm{a}}$ \\
\hline Organic matter & $\mathrm{n} . \mathrm{s}$. & $\mathrm{n} . \mathrm{s}$. & $\mathrm{n} . \mathrm{s}$. & $11.28^{\mathrm{ab}}$ \\
\hline Phosphorus & $10.43^{\mathrm{ab}}$ & $7.33^{\mathrm{a}}$ & $19.7^{\mathrm{b}}$ & $53^{\mathrm{a}}$ \\
\hline Potassium & $68^{\mathrm{a}}$ & $135.3^{\mathrm{b}}$ & $181.3^{\mathrm{b}}$ & $0.08^{\mathrm{a}}$ \\
\hline Aluminum & $0.9^{\mathrm{b}}$ & $0,3^{\mathrm{a}}$ & $0.1^{\mathrm{a}}$ & $5.48^{\mathrm{c}}$ \\
\hline Calcium & $3.4^{\mathrm{a}}$ & $4.05^{\mathrm{ab}}$ & $5.1^{\mathrm{bc}}$ & \\
\hline
\end{tabular}

The ordination diagram (Figure 1) illustrates the changes of annual ryegrass SSB throughout the year and soil

FIGURE 1. Ordination diagram of $L$. multiflorum soil seed bank data $(0-10 \mathrm{~cm})$ throughout the year in the plots of 6,8 , and 9 year-old chronosequences $(n=11)$. The variables $\mathrm{pH}$, organic matter (MO), potassium (K), sodium (Na), and calcium (Ca) levels in the soil have a correlation index of more than 0.52 with the $X$ axe. The horizontal axe represents $53,8 \%$ and the vertical axe $33,1 \%$ of seed bank variation throughout the year. chemical composition in three chronosequences (6, 8 and 9 years-old).

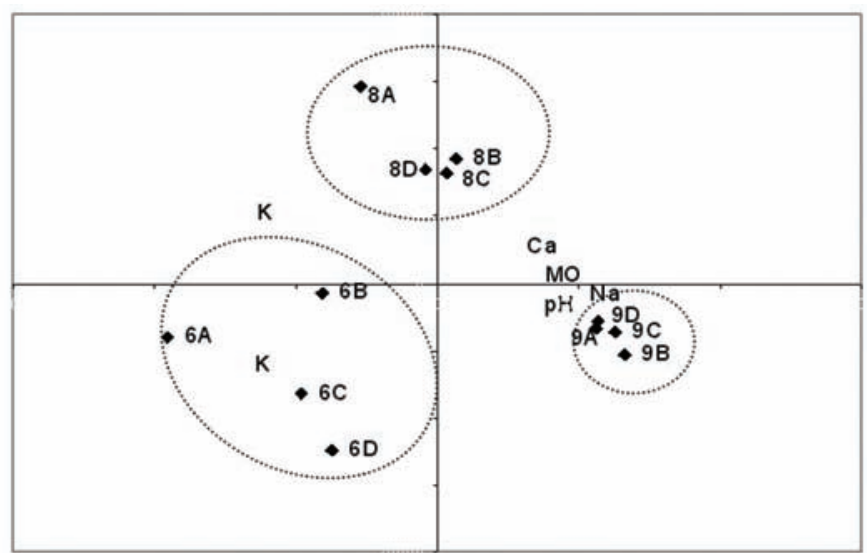


The soil of the area that was managed for 3 years had the highest indexes of aluminium and organic matter. The soil of the 6 year-old area had the highest clay content. The soil that was managed for 8 years had the highest indexes of potassium, phosphorus and magnesium.

The soil of the 9 year-old area had the highest indexes of sodium and $\mathrm{pH}$. In Figure 1 we can see the possible influences of potassium on the SSB of 6 and 8 year-old chronosequences, both with soybean during the evaluation period, and $\mathrm{pH}$, calcium and organic matter of the soil on the SSB of 9 year-old chronosequence.

At the end of the summer (end of February and March), dormancy of most seeds in the soil was overcome and consequently a decrease of $49 \%$ to $82 \%$ in the soil seed bank size was observed, which coincides with the beginning of the increase in the seedling number. In the first month of autumn (April), more than $90 \%$ of seeds had germinated. In May, the seed bank became insignificant and the number of seedlings reached its maximum, decreasing after that. An expressive number of plants was observed during this period, increasing until the beginning of the winter and decreasing and getting stabilized after that. In the beginning of the spring (end of September), first flowers appeared. At the end of the spring (end of November and December), seed deposition in the soil began.

There were significant differences $(\mathrm{P}<0.05)$ in the size of the soil seed bank from 0-10 cm between the chronosequences from the end of spring, when dispersion of seeds started, to the beginning of autumn, when the germination peak occurred, and no differences from the end of autumn to the next spring, when almost no seeds could be found in the soil (Table 2). The seeds from the $5-10 \mathrm{~cm}$ depth did not show significant differences between the sites $(\mathrm{P}>0.05)$.

TABLE 2. Changes in the size of annual ryegrass soil seed bank $(0-10 \mathrm{~cm})$ in the 6,8 , and 9 year-old chronosequences $(\mathrm{P}<.05)$. Different symbols indicate significant differences between means using One-Way ANOVA followed by Tukey's range test of log transformed data. Read horizontally only.

\begin{tabular}{|c|c|c|c|}
\hline Sampling time & 6 years-old & 8 years-old & 9 years-old \\
\hline September & n.s. & n.s. & n.s. \\
\hline October & n.s. & n.s. & n.s. \\
\hline November & $22,835^{\text {a }}$ & $6,203^{\text {b }}$ & $2,458^{c}$ \\
\hline December & $13,831^{\mathrm{a}}$ & $13,398^{\text {a }}$ & $6,623^{\mathrm{b}}$ \\
\hline January & $13,194^{\mathrm{a}}$ & $18,824^{\text {a }}$ & $4,941^{b}$ \\
\hline February & $3,248^{a}$ & $7,909^{\mathrm{b}}$ & $319^{c}$ \\
\hline March & $2,700^{a}$ & $8,801^{\text {b }}$ & $904^{\mathrm{a}}$ \\
\hline April & n.s. & n.s. & n.s. \\
\hline May & n.s. & n.s. & n.s. \\
\hline June & n.s. & n.s. & n.s. \\
\hline July & n.s. & n.s. & n.s. \\
\hline August & n.s. & n.s. & n.s. \\
\hline
\end{tabular}

Figure 2 shows the gradual differences in time of the seed bank size in the first $5 \mathrm{~cm}$ of soil in each chronosequence. The seeds from the 5-10 cm depth were not considered as the sample variances were not equal (Levene Statistic with $\mathrm{P}<0.05)$. Even not considering the 3 year-old chronosequence in some analysis, it was possible to see significant differences $(\mathrm{P}<.05)$ between the size of seed bank in summer (from December to March) and in autumn (May).

In the 6 and 8 year-old chronosequences, there was a significant difference $(\mathrm{P}<.05)$ between the period where the plants were flowering, which starts in the end of winter and beginning of spring (September), where no seeds could be found in the soil, and the period when the dispersion started, at the end of spring (end of November). During autumn, when most seeds germinate, it was still possible to find few seeds in the soil (from May to July). The soil seed bank started decreasing after May, where the highest number of seedlings was found (Figure 3), with a drastic reduction in June and July, reaching zero values in August. 
FIGURE 2. Results from One-Way ANOVA for changes in the size of annual ryegrass soil seed bank throughout the year in the $6(\mathrm{~A}), 8(\mathrm{~B})$ and $9(\mathrm{C})$ year-old chronosequences $(\mathrm{P}<.05)$.

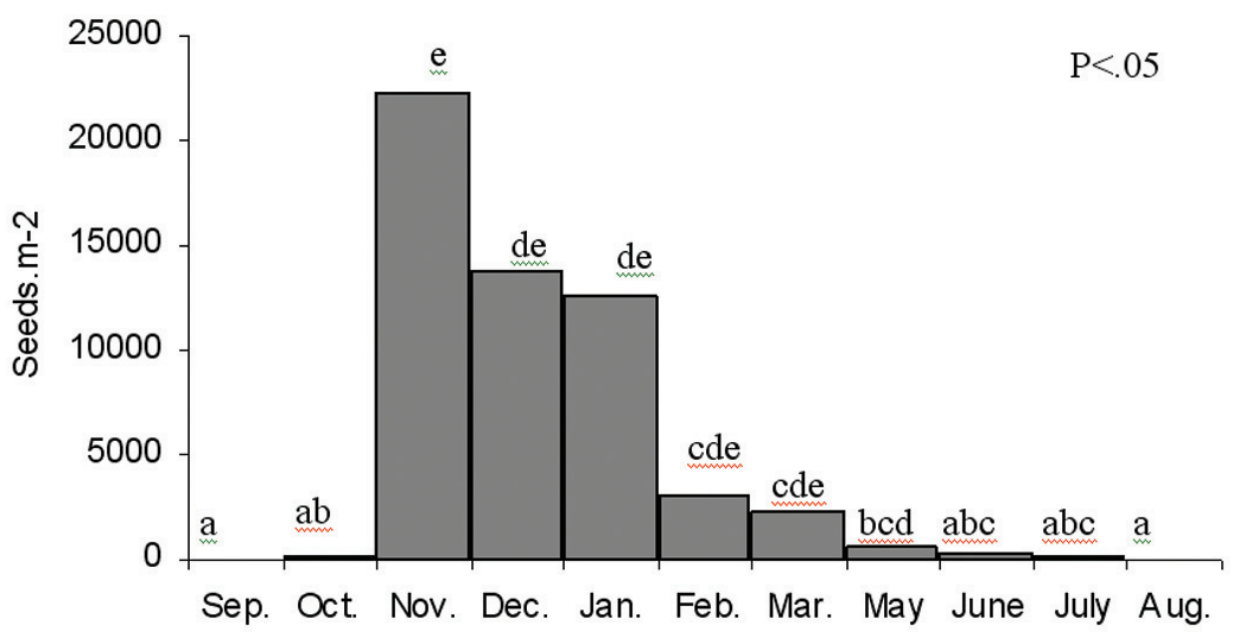

Sampling time
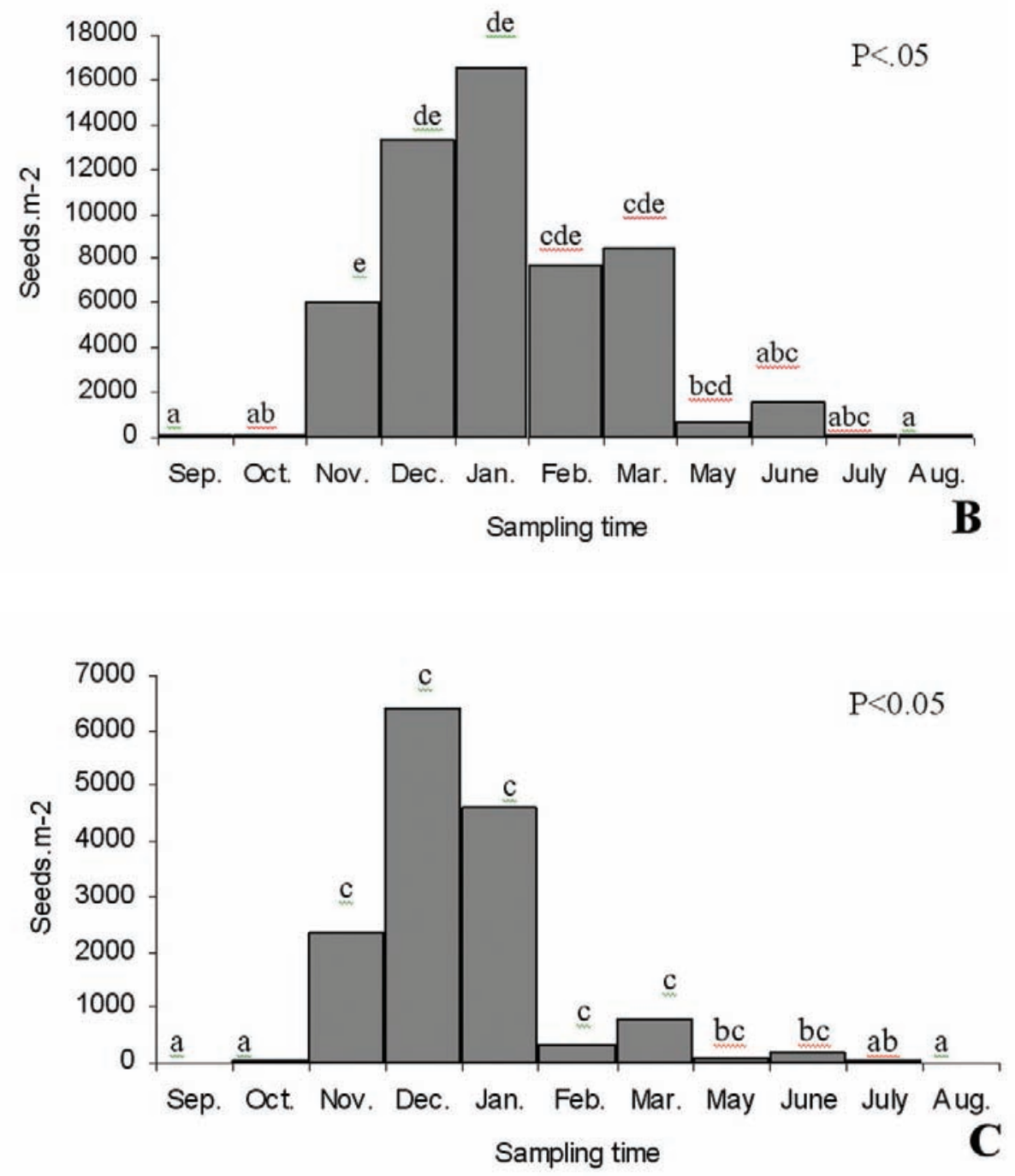
FIGURE 3. Dynamics of annual ryegrass vegetation in the 6 (A), 8 (B) and 9 (C) year-old chronosequences.

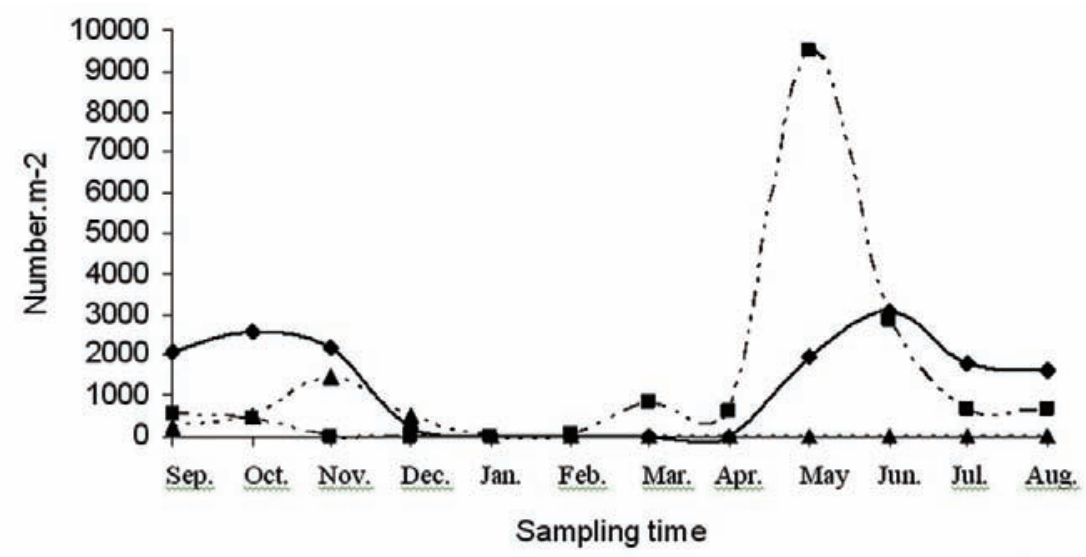

$\longrightarrow$ Plants $-\cdot--$. Seedlings $\cdots \Delta \cdot$. Flower sets

A
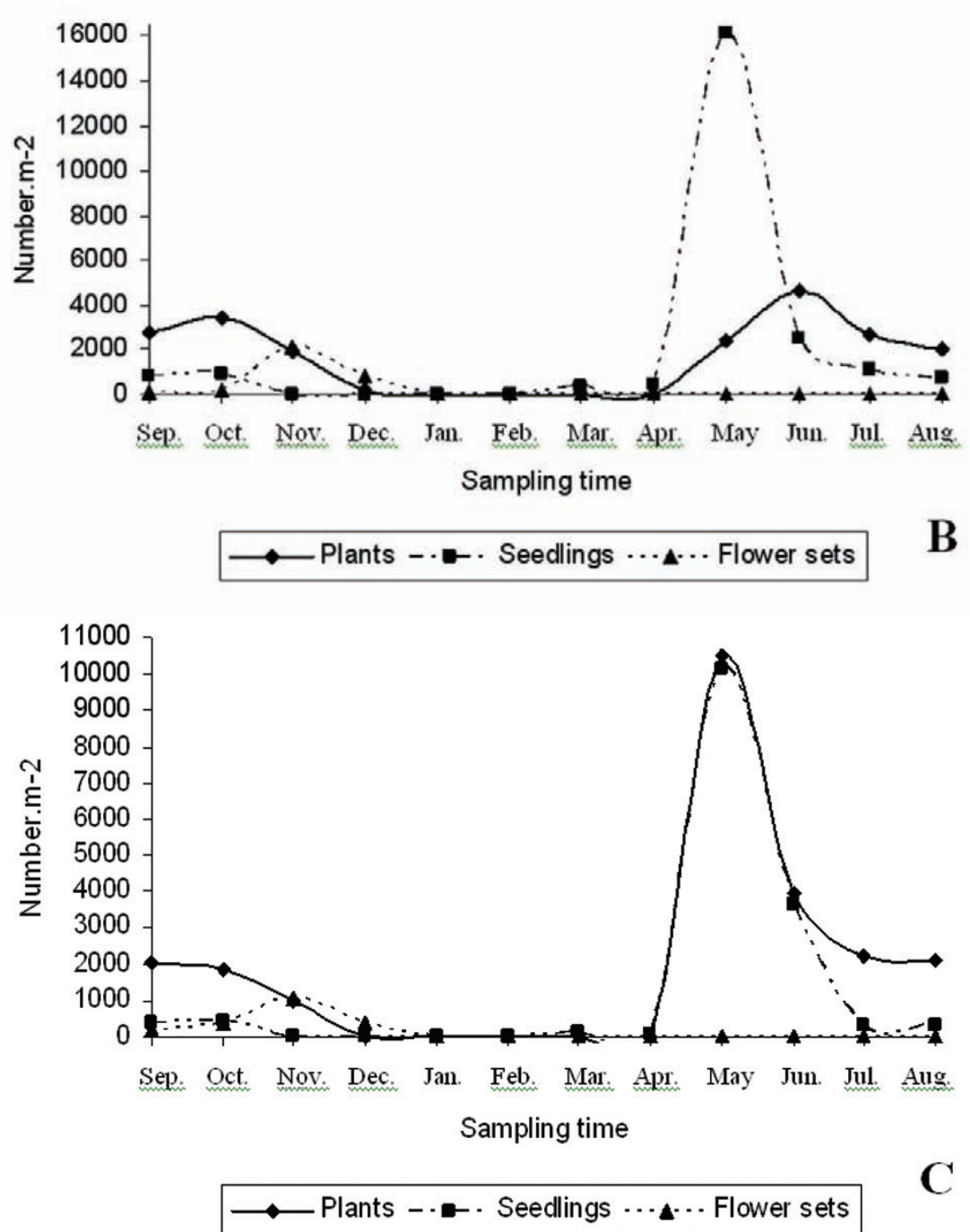
These differences were also significant $(\mathrm{P}<0.05)$ for the 9 year-old chronosequence that had no crop during the study period, but the decrease in the seed bank started earlier (end of March). However, the peak in seedling number was also in May (Figure 3).

The species associated to no tillage systems have a transitory SSB; they germinate in autumn and have predictable dynamics (Silva, 2004) as L. multiflorum in this case. If we consider that the longevity of this species is also short in natural conditions (Thompson et al., 1997; see the paper subsequent to this one, published as section II), the observed pattern of the soil seed bank, where almost all seeds germinate after less than six months after dispersion, is totally comprehensible.

The cubic model appeared to provide the best description for the soil seed bank dynamics of $L$. multiflorum in all chronosequences and depths (Figure 4 and Table 3). It is possible to identify three distinct periods in these models. The first period is in spring (September and October), when plants start flowering and forming seeds, with almost no seeds in the soil. The second period is from the end of the spring to summer (from November to March), when seed dispersion and a small period of dormancy in the soil take place. In this period, marked in Figure 4, we observe the highest number of seeds in the soil and also significant differences $(\mathrm{P}<0.05)$ in soil seed bank size between the three chronosequences. About dormancy, Bazzigalupi (1982) mentions absence of germination in L. multiflorum seeds just after harvest, increasing gradually and reaching the peak after three months of storage, which coincides with the germination conditions in the field. The third period begins when seed germination starts in autumn (April), showing a strong decrease in the number of seeds in the soil, reaching zero values in winter (August). Freitas (1990) and Silva (2004) found similar results when studying soil seed bank dynamics of two other grasses: Brachiaria plantaginea and Bromus auleticus, respectively; the first species, an annual weed, and the second, a species native to grasslands in the South of Brazil, Uruguay and Argentina. Both species also showed a germination peak in March and April (end of summer and beginning of autumn). The first one in adequate moisture conditions ("Cerrado") and the second in the beginning of autumn (South Brazilian grasslands).

FIGURE 4. Curve fit of annual ryegrass soil seed bank collected from September to August, 2003.

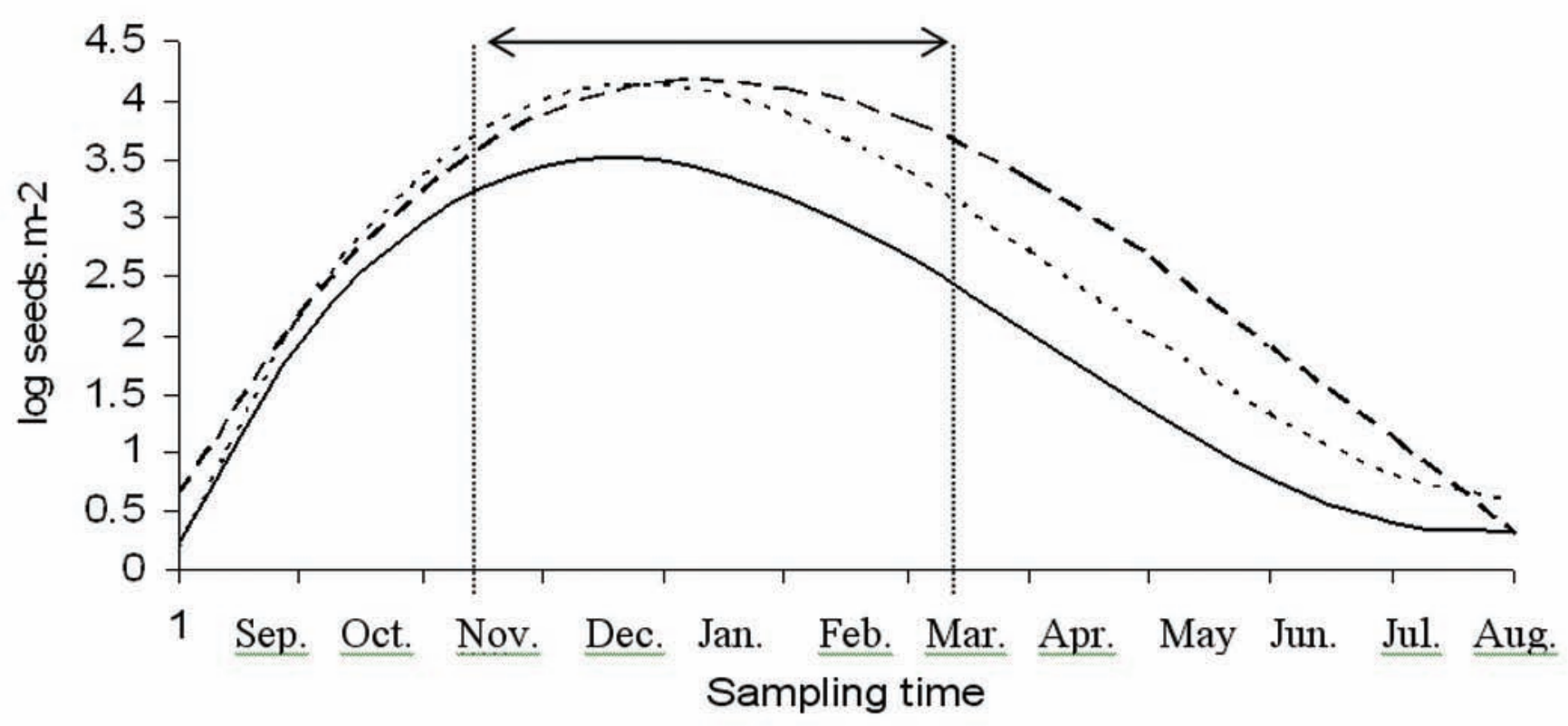

$\ldots+6.6$ years-old ----8 years-old _-9 years-old 
TABLE 3. Cubic regression models of log-transformed data of annual ryegrass soil seed bank for each chronosequence $(\mathrm{P}<.001)$.

\begin{tabular}{ccc}
\hline $\mathrm{n}=40$ & Viable seeds $(\mathrm{y})$ & $\mathrm{R}^{2}$ \\
\hline 6 years-old & $\begin{array}{c}\mathrm{y}=3.1973 \mathrm{x}- \\
0.4618 \mathrm{x} 2+0.0181 \mathrm{x} 3-2.5740\end{array}$ & 0.72 \\
\hline 8 years-old & $\begin{array}{c}\mathrm{y}=2.3323 \mathrm{x}- \\
0.2879 \mathrm{x} 2+0.0088 \mathrm{x} 3-1.4246\end{array}$ & 0.71 \\
\hline 9 years-old & $\begin{array}{c}\mathrm{y}=2.8737 \mathrm{x}- \\
0.4354 \mathrm{x} 2+0.0178 \mathrm{x} 3-2.2169\end{array}$ & 0.71 \\
\hline
\end{tabular}

This pattern was observed for both depths (0-5 and 5-10 $\mathrm{cm})$. Even being a no tillage system, the dynamics of the seeds 5-10 cm deep in the soil were not stable, showing the same decrease of seeds in the soil in the end of autumn (around May), where no seeds were found, and the same increase in the end of spring (end of November), when seeds were dispersed, but, of course, in small scale due to the few amount of seeds. This happens because of the machine used to open small furrows in the soil during soybean sowing. The soybean is sown at an approximate depth of $2 \mathrm{~cm}$ and the fertilizer is placed 5-7 cm around the seeds. This allows the seeds that are in the surface and in the first layers to penetrate deeper in the soil.

Small differences could be observed between chronosequences with and without soybean during the sampling period. Soil seed bank dynamics was the same, but the decrease in the seed bank of the chronosequence without soybean (9 years-old) started earlier (end of March) as the crop shade did not exist in this case. However, the peak in the number of seedlings was also in May (Figure 3), as in the other chronosequences. In this period of the year, natural grassland vegetation was still covering the area, but most of it was formed by prostrate species due to grazing. In this way, the small seedlings that emerge in summer were directly exposed to the sun and died in the early stages.

Seed survival and seed bank size can depend on seed burial and habitat conditions, seed age, density and predation, and on factors, such as herbivory, that affect seed inputs (Alexander and Schrag, 2003). We expected that management time would be the main factor affecting soil seed bank size, with the 9 year-old chronosequence showing the biggest number of seeds in the soil. However, management practices used on each site were more important. Sites with soybean had a great influence on annual ryegrass soil seed bank. The crop creates some conditions which protect the grass seedlings in the beginning of their development, such as shade during summer time, allowing a decrease in the mortality rate of the seedlings.

Besides, fertilizer applications to the crop also allow better nutrient conditions to the grass. Some of the soil variables evaluated in this study allowed significant differences in soil fertility indexes, mainly between the areas with and without soybean, as the 9 year-old chronosequence. The nitrate, for example, can promote the germination of non-dormant seeds (Fenner and Thompson, 2005).

The response to nitrate is interpreted as dormancybreaking by some authors (Pons, 1989), as well as a promotion of germination in non-dormant seeds by others (Fenner and Thompson, 2005). The internal nitrate content of seeds has a clear correlation with germinability (Bouwmeester et al., 1994). However, nitrate is readily leached out of seeds in the soil, making the endogenous content less ecologically significant than the sensitivity of the seed to external nitrate ions (Murdoch and Carmona, 1993 apud Fenner and Thompson, 2005; Bouwmeester et al., 1994).

Pons (1989) showed that the response to nitrate could be used as a mechanism of the seeds to detect gaps in the vegetation, due to the reduction of this nutrient because of its being taken up by the plants root system, the effect of disturbance and the season of the year. In many cases, the germination response to nitrate is highly influenced by other factors such as light and fluctuating temperatures (Probert et al., 1987). Since these three factors (nitrate, light and temperature fluctuations) all change simultaneously when a gap is created in the vegetation, a response to the three of them would form an effective gap-detecting mechanism (Fenner and Thompson, 2005).

A newly emerged seedling is also at a great disadvantage with established plants in capturing resources before the formation of its roots and expansion of its leaves (Fenner and Thompson, 2005), as well as those from the natural vegetation that covered the 3 and 9 year-old chronosequences. Schafer and Chilcote (1970, apud Baskin and Baskin, 2000) report the germination of buried L. multiflorum seeds followed by the death of the seedlings before emergence, what was also observed in this study. The availability of suitable micro sites for establishment can also limit the recruitment.

These conditions reflect the situation observed in the field, 
where sites with soybean showed a larger number of seeds in the soil than sites without soybean. These chronosequences with crop had better nutrient conditions according to the soil fertility analysis, mainly potassium and phosphorus, and also more gaps available for establishment of the seedlings, as the weed control was systematic and highly efficient. The ordination diagram of Figure 1 shows exactly the influence of potassium index in the soil, for example, on the seed bank of 6 and 8 year-old chronosequence, which were fertilized with potassium due to soybean cultivation.

As we can see, the natural re-sowing of the pasture is totally dependent on the annual recruitment of seeds and the influence of the management practices is much more important than the number of years that these practices have been carried out. The size of annual ryegrass soil seed bank is positively associated to soybean crop, whose integration allows better seedling survival and anticipates forage production.

Short and seasonal delays in germination are frequently associated to some kind of dormancy (Thompson, 2000). The present study revealed that most of the annual ryegrass seeds overcome dormancy and germinate in the end of summer and beginning of autumn.

Several schemes have been published aiming at describing and classifying the different types of seed bank (Csontos and Tamas, 2003). Here we use the scheme proposed by Thompson et al. (1997). In this case, L. multiflorum was classified as having a transitory (viable in the soil for less than one year) to short-term persistent (viable for one to five years) type of seed bank, what agrees with results obtained in other countries (Douglas, 1965; Howe and Chancellor, 1983; López-Mariño et al., 2000).

\section{CONCLUSIONS}

The soil seed bank dynamics of annual ryegrass shows a structural pattern in time, with a "storage" period in summer, an "exhausting period" during autumn and a "transition period" in winter and spring.

The establishment of the pasture by natural re-sowing is totally dependent on the annual recruitment of seeds from the soil.

The management practices have a bigger influence on the soil seed bank than the number of years these practices have been implemented.

The size of annual ryegrass soil seed bank is positively associated to soybean crop, whose integration allows better seedling survival and anticipates forage production.
The majority of seeds overcome dormancy and germinate in the end of summer and beginning of autumn, showing a typically transitory soil seed bank, but with a small proportion of persistent seeds.

\section{REFERENCES}

ALEXANDER, H.M.; SCHRAG, A.M. Role of soil seed banks and newly dispersed seeds in population dynamics of the annual sunflower, Helianthus annuus. The Journal of Ecology, Oxford, v.91, p.987-998, 2003.

AYALA, W. Rol del banco de semillas en la persistencia de pasturas mejoradas. In: REUNIÓN DE GRUPO TÉCNICO EN FORRAJERAS DEL CONO SUR - ZONA CAMPOS, 19., Mercedes. Anais... Mercedes: INTA, 2002. p.188.

BARCELLOS, J.O.J.; PRATES, E.R.; SILVA, M.D.; MONTANHOLI, Y.R.; WUNSCH, C. Sistemas pecuários no sul do Brasil - Zona Campos: tecnologias e perspectivas. In: REUNIÓN DE GRUPO TÉCNICO EN FORRAJERAS DEL CONO SUR - ZONA CAMPOS, 19., Mercedes. Anais... Mercedes: INTA, 2002. p.10-15.

BASKIN, C.C.; BASKIN, J.M. Seeds: ecology, biogeography, and evolution of dormancy and germination. 2 ed. San Diego: Academic Press, 2000. 666p.

BAZZIGALUPI, O. Efeito da época de colheita sobre o rendimento e a qualidade de sementes de azevém anual. 1982. 74 f. Dissertação (Mestrado em Ciência e Tecnologia de Sementes) - Faculdade de Agronomia Eliseu Maciel, Universidade Federal de Pelotas, Pelotas.

BOUWMEESTER, H.J.; DERKS, L.; KEIZER, J.L.; KARSSEN, C.M. Effects of endogenous nitrate content of Sisymbrium officinale seeds on germination and dormancy.

Acta Botanica Neerlandica, v.43, p.39-50, 1994.

BRASIL. Ministério da Agricultura e Reforma Agrária. Regras para análise de sementes. Brasília, DF: SNDA/ DNDV/CLAV, 1992. 365p.

CSONTOS, P.; TAMAS, J. Comparisons of soil seed bank classification systems. Seed Science Research, Wallingford, v.13, p.101-111, 2003.

DOUGLAS, G. The weed flora of chemically-renewed lowland swards. Journal of the British Grassland Society, London, v.20, p.91-100, 1965.

FENNER, M. ; THOMPSON, K. The ecology of seeds. Cambridge: Cambridge University Press, 2005. 250p.

FREITAS, R.R. Dinâmica do banco de sementes em uma comunidade de plantas daninhas com aspectos da germinação e dormência de sementes de capim- 
marmelada (Brachiaria plantaginea (Link) Hitc.). 1990. 118 f. Tese (Mestrado) - Escola Superior de Agricultura de Lavras, Lavras.

HAYASHI, I.; NUMATA, M. Viable buried-seed population in the Miscanthus- and Zoysia-type grasslands in Japan: Ecological studies on the buried-seed population in the soil related to plant succession. VI. Japanese Journal of Ecology, v.20, p.243-252, 1971.

HOWE, C.D.; CHANCELLOR, R.J. Factors affecting the viable seed content of soils beneath lowland pastures. The Journal of Applied Ecology, London, v.20, p.915-922, 1983.

IBGE. Disponível em : < www.ibge.gov.br/ > Acesso em 2005.

LÓPEZ-MARIÑO, A., LUIS-CALABUIG, E., FILLAT, F.; BERMUDEZ, F.F. Floristic composition of established vegetation and the soil seed bank in pasture communities under different traditional management regimes. Agriculture, Ecosystems and Environment, Tókio, v.78, n.3, p.273-282, 2000.

MAIA, F.C., MEDEIROS, R.B., PILLAR, V.P., FOCHT, T., CHOLLET, D.M.S.; OLMEDO, M.O.M. Composição, riqueza e padrão de variação do banco de sementes do solo em função da vegetação de um ecossistema de pastagem natural. Iheringia, v.58, n.1, p.61-80, 2003.

MAIA, M.S.; PRIMO, A.T. Cadeia forrageira para a região sul. In: FEDERACITE (Org.). Cadeias forrageiras regionais. Porto Alegre: Caramuru, 1995. p.106-132.

MARAÑON, T. Ecologia de los bancos de semilla en el suelo: una revisión de estúdios españoles. Pastos, v.25, n.1, p.3-25, 1995.

MEDEIROS, R.B. Bancos de sementes no solo e dinâmica vegetal. In: REUNIÃO DO GRUPO TÉCNICO REGIONAL DO CONE SUL (ZONA CAMPOS), 18., Guarapuava. Anais... Guarapuava: CPAF/FAPA, 2000. p.61-87.

NUMATA, M., AOKI, K.; HAYASHI, I. Ecological studies on the buried-seed population as related to plant succession. II-Particularly on the pioneer stage dominated by Ambrosia elatior. Japonese Journal of Ecology, Tókio, v.14, p.224227, 1964.

PILLAR, V.P. Multivariate exploratory analysis and randomization testing with MULTIV. Coenoses, v.12, p.145-148, 1997.

PILLAR, V.P.; ORLÓCI, L. Character-based community analysis: the theory and an application program. The Hague: SPB, 1993. 270p. (Ecological Computation Series, v.5).

PONS, T.L. Breaking of seed dormancy by nitrate as a gap detection mechanism. Annals of Botany, Oxford, v.63, p.139-143, 1989.

PROBERT, R.J., GAJJAR, K.H. AND HASLARN, I.K. The interactive effects of phytochrome, nitrate and thiourea on the germination response to alternating temperatures in seeds of Ranunculus sceleratus L.: a quantal approach. Journal of Experimental Botany, Oxford, v.38, p.1012-1025, 1987.

SILVA, G.M. Aspectos fisiológicos e ecológicos da produção de sementes de cevadilha-vacariana (Bromus auleticus Trinius). 2004. 110 f. Tese - Universidade Federal de Pelotas, Pelotas.

THOMPSON, K. The functional ecology of seed banks. In: FENNER, M. (Ed.). Seeds: the ecology of regeneration in plant communities, Wallingford: CABI, 2000. p.215-235.

THOMPSON, K.; GRIME, J.P. Seasonal variation in the seed banks of herbaceous species in ten contrasting habitats. The Journal of Ecology, Oxford, v.67, p.893-921, 1979.

THOMPSON, K.; BAKKER, J.P.; BEKKER, R.M. The soil seed banks of North West Europe: methodology, density and longevity. Cambridge: Cambridge University Press, 1997. 276p.

THOMPSON, K.; CERIANI, R.M.; BAKKER, J.P.; BEKKER, R.M. Are seed dormancy and persistence in soil related? Seed Science Research, Wallingford, v.13, p.97100, 2003. 